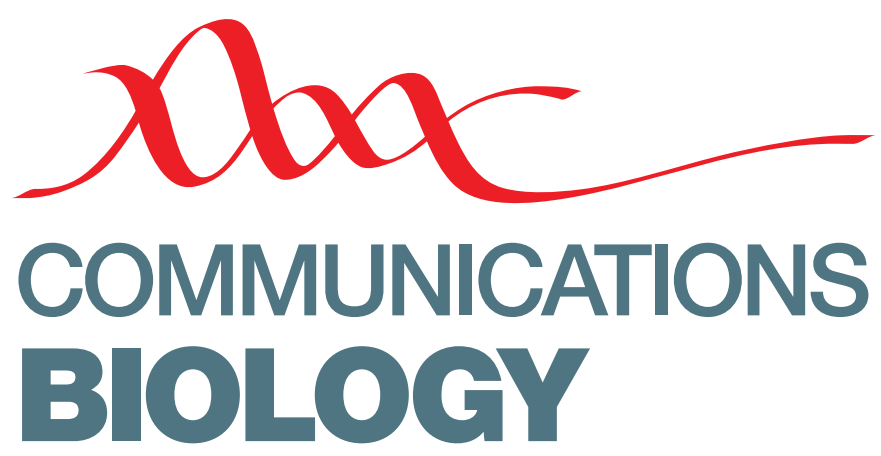

https://doi.org/10.1038/s42003-019-0724-8 OPEN

\title{
Publisher Correction: A TonB-dependent receptor constitutes the outer membrane transport system for a lignin-derived aromatic compound
}

\author{
Masaya Fujita (1), Kosuke Mori, Hirofumi Hara, Shojiro Hishiyama, Naofumi Kamimura (i) \& Eiji Masai (1)
}

Correction to: Communications Biology https://doi.org/10.1038/s42003-019-0676-z, published online 22 November 2019.

In the original published version of the article, a correction to Figure $2 \mathrm{c}$ was not carried out prior to publication. All samples were incorrectly labelled as having been treated with $1 \mathrm{mM}$ DDVA. The leftmost lane for SYK-6, $\Delta d d v T$ and $\Delta d d v R$ samples shown in the blot should have been marked as untreated. The error has been corrected in the HTML and PDF versions of the article.

Published online: 17 December 2019

\begin{abstract}
(c) (i) Open Access This article is licensed under a Creative Commons Attribution 4.0 International License, which permits use, sharing, adaptation, distribution and reproduction in any medium or format, as long as you give appropriate credit to the original author(s) and the source, provide a link to the Creative Commons license, and indicate if changes were made. The images or other third party material in this article are included in the article's Creative Commons license, unless indicated otherwise in a credit line to the material. If material is not included in the article's Creative Commons license and your intended use is not permitted by statutory regulation or exceeds the permitted use, you will need to obtain permission directly from the copyright holder. To view a copy of this license, visit http://creativecommons.org/licenses/by/4.0/.
\end{abstract}

(C) The Author(s) 2019 